\title{
SOUTH KOREA'S (INCOMPLETE) MIDDLE-POWER DIPLOMACY TOWARD ASEAN
}

\author{
Brendan Howe* \\ Graduate School of International Studies, Ewha Womans University, \\ 52 Ewhayeodae-gil, Seodaemun-gu, 03760, Seoul, Republic of Korea \\ E-mail: bmg.howe@gmail.com \\ Min Joung Park** \\ Graduate School of International Studies, Ewha Womans University, \\ 52 Ewhayeodae-gil, Seodaemun-gu, 03760, Seoul, Republic of Korea \\ E-mail: minjoung_park@ewhain.net
}

Published online: 15 July 2019

To cite this article: Howe, B. and Park, M. J. 2019. South Korea's (incomplete) middle-power diplomacy toward ASEAN. International Journal of Asia Pacific Studies 15 (2): 117-142, https://doi.org/10.21315/ijaps2019.15.2.5

To link to this article: https://doi.org/10.21315/ijaps2019.15.2.5

\begin{abstract}
This paper highlights Seoul's middle-power activism toward the most important multilateral organisation in its near abroad, the Association of Southeast Asian Nations (ASEAN). It reviews how the successive administrations of Roh Moo-hyun (2003-2008), Lee Myung-bak (2008-2013) and Park Guen-hye (2013-2016) strove to assert Korean middle-powerism based on the conceptual foundations of their respective discourses. This paper argues that although South Korea's strategic role as a middle power toward ASEAN had been limited due to the geopolitical rivalry between the United States and China, in the future this rivalry may open a new avenue of potential to increase South Korea's strategic role as a middle power, appealing to ASEAN and its member states. In order to make good use of this opportunity, this paper recommends South Korea to deepen and broaden its engagement of with humanitarian norm-promoting organisations within ASEAN, especially the ASEAN Intergovernmental Commission of Human Rights (AICHR) and the ASEAN Coordinating Centre for Humanitarian Assistance on disaster management (AHA Centre), and acknowledgement of the opportunity that other
\end{abstract}


non-traditional security (NTS) issues provide for greater dialogue and cooperation with ASEAN.

Keywords: Korea-ASEAN relations, middle power, Korea's foreign policy, multilateralism, ASEAN

\section{INTRODUCTION}

Over the last three decades, the Association of Southeast Asian Nations (hereafter, ASEAN) has been a substantial focus in South Korea's foreign and economic policy and the two sides have established many areas of dialogue and cooperation. The Republic of Korea (ROK) has been an invaluable developmental partner, using official development assistance (ODA) to foster regional economic growth, and relying on its own development experience as a guide for economic industrialisation in states in the region. Korea's economic presence in the region is also considerable, accounting for USD 5.3 billion in foreign direct investment (FDI) into ASEAN member states in 2016 (Korea Eximbank). Two-way trade between ASEAN members and Korea stood at USD 119 billion in 2016, which made ASEAN Korea's second largest trading partner (MOTIE 2017). More recently, in the face of traditional challenges and non-traditional security (NTS) threats, including piracy and terrorism, Korea has emerged as a more proactive partner in offsetting critical strategic risks.

This trend is expected to be further intensified based on the ROK's "New Southern Policy." This platform, announced during President Moon Jae-in's tour of three Southeast Asian nations in November 2017, seeks to elevate the relationship between South Korea and ASEAN to the same level as the one between the ROK and its four strategic partners - the United States, Russia, China and Japan (Sohn 2017). In line with Moon's domestic policy of a "people-oriented economy," the basic idea of the New Southern Policy is to form a people-centred peace community that advocates co-prosperity (Moon 2017). As part of the New Southern Policy, President Moon pledged, by 2019, to double to USD 14 million the ASEAN-ROK Cooperation Fund (AKCF) (Moon 2017).

Established in 1990 at USD 1 million per year, the AKCF is the Korean government's main institutional contribution to ASEAN (Suh 2017). As a mean of furthering South Korea's diplomatic engagement and developmental partnership with ASEAN, about 400 cooperation projects have been implemented through the AKCF, with emphasis on the areas of education, environment and culture, in order to enhance capacity-building 
and to strengthen people to people exchanges (ASEAN Secretariat 2017b). Indeed, perhaps nowhere can the impact of Korea's diplomatic activism be felt more strongly than in ASEAN. Such policies are redolent of the "niche diplomacy" pursued by middle powers, in which states which lack either the resources or political will to dominate the community of states, or coerce their neighbours, instead identify specific issue areas that are not or cannot be dictated by great powers and concentrate their full efforts on it to take relative advantage (Cooper 1997). Former Australian Foreign Minister Gareth Evans was a pioneer and champion of this strategy from the mid-1980s (Lee and Park 2017).

South Korea has faced considerable diplomatic challenges, however, both in terms of its middle-power activism in general, and more specifically, with regard to its engagement with Southeast Asia. In the security field, due to geopolitical constraints, the ROK is unable to perform the neutral or brokering role of traditional middle powers (Kalinowski and Cho 2012: 244). In terms of regional security, Korea's middle-powerism towards ASEAN is limited by the hierarchical conceptualisation of middle power which continues to constrain Korea due to the power-deficit vis-à-vis stronger regional players.

In the ASEAN Regional Forum (hereafter, ARF), which has been attended by the Democratic People's Republic of Korea (DPRK) since $2000^{1}$ as well as the other five members of the now suspended Six Party Talks (United States, Japan, South Korea, China and Russia), Seoul had been unable fully to utilise this rare opportunity to engage with major regional players on nuclearising the Korean Peninsula. For example, in 2008, South Korea tried to have the issue of North Korean provocation added to the agenda of the ARF, but ASEAN refused to countenance discussion of such a sensitive issue (Hundt 2012: 202). Although it was treated as one of the main agendas of two successive recent ARF meetings in 2017 and 2018 (ARF 2017, 2018), this would not have been possible without the diplomatic support from the Trump administration on this issue (Lee 2017) as well as the leadership of the Philippines and Singapore, the ASEAN chair for 2017 and 2018, respectively.

South Korea's strategic constraints or restraint is also reflected in Seoul's engagement on politically sensitive issues such as the South China Sea. Unlike other middle powers, such as Australia and Japan, which have jointly challenged China on this issue since 2010, South Korea has been stayed out of this regional affairs (Jackson 2015; Green 2017). Seoul's "strategic" silence has been criticised for its diplomatic naivety since it has been turning a blind eye in hopes of winning China's future support in the event of any contingency involving North Korea (Jackson 2015). 
Yet alternative conceptualisations of middle-powerism, and activism in realms beyond those associated with traditional security, reveal not only a greater and more proactive role already being played by the ROK in Southeast Asia, but also potential future avenues through which Korea can punch above its weight. In such a context, therefore, this paper argues that Korea has sought to balance between the leadership role of a rising middle power toward ASEAN and followership of, or bandwagoning with its strategic partners, the United States and China. Hence the notion of "incomplete" middle-power diplomacy in the region. If successfully implemented President Moon's New Southern Policy, however, there is a new avenue of potential to increase South Korea's strategic role as a middle power, appealing to ASEAN and its member states, especially under the current condition of the growing rivalry of the United States and China in the Asia-Pacific region.

The paper begins with a discussion on middle-power diplomacy and competing theoretical perspectives. It then reviews how the administrations of Roh Moo-hyun (2003-2008), Lee Myung-bak (2008-2013) and Park Guen-hye (2013-2016) strove to assert Korean middle-powerism based on the conceptual foundations of their respective discourses. This is followed by analysis of Korea's middle-power policy towards ASEAN, including the strategic limitations faced. The prospects for the New Southern Policy and related middle power initiatives are then analysed in the strategic context. Finally, the concluding analytical section includes limited policy prescription for the ROK government.

\section{THEORETICAL DISCUSSION ON MIDDLE-POWER DIPLOMACY}

The notions of what it is to be a middle power and how the power of aspirants is to be measured are challenging to define. Ashley Tellies et al. (2000: 1314) note that most notions of power boil down to references to "allocation of resources," "ability to use these resources," and the "strategic character" of power, meaning its use not only against inertia, but also opposing wills. "This tripartite approach to power can be restated using a simple taxonomy that describes power as 'resources,' as 'strategies' and as 'outcomes."' Thus, a middle power is one that has somewhat middling access to resources, pursues strategies appropriate to middle-powerism, and/or has a modest ability to impact on the external operating environment (Howe 2017: 243-244). Middle powers lack "compulsory power," the military resources to dominate other 
countries or the economic resources to bribe countries into adopting policies that they would not otherwise pursue. Yet they differ from the small or "system ineffectual" states which have little or no influence. They are, potentially, "system affecting states" which can have a significant impact within a narrower policy area, or in conjunction with others (vom Haua et al. 2012: 187-188).

In practical terms, the notion of middle power was publicly introduced with the end of World War II (Lee and Park 2017). Unsatisfied with strategies dictated by great powers, Canada, Australia and Nordic countries sought for opportunities to assert their positions in the new United Nations (UN) system (Holmes 1967). Yet because international society was divided by ideological confrontation during the Cold War, and due to related strategic limitations, proactive middle-powerism was limited for much of this period, with states possessing middling resources either bandwagoning with great powers or pursuing neutralism and nonalignment diplomacy. In 1983, however, the "Western Middle Powers and Global Poverty" project was initiated and participated in by Canada, the Netherlands, Sweden, Norway and Denmark; the first concrete cooperative effort among middle powers. Through the publications of the project, issues related to human rights emerged as the most instrumental subjects upon which middle powers could effectively exert their influence (Pratt 1990).

Serious research on the concept of "middle power in international politics" began with Carsten Holbraad during the early 1970s. In order to criticise the simple dichotomy between great powers and the rest, Holbraad (1971) emphasised the importance of the mid-sized state and attempted to evaluate the function of certain states by observing physical capacities related to economy, military and population, defining states that are situated between great powers and weak states as middle powers. Laura Neack (1992) was also among those who took a power-political or realist perspective in categorising middle powers by emphasising and expanding upon such "resource power" measurements as had been introduced by Holbraad. Yet, structural perspectives based on realism are criticised for being too rigid to observe the constant changes through which states go in the international system (Sohn 2016).

On the other hand, liberal scholars emphasise "middlepowermanship," which relates to the diplomatic behaviour and intentions of certain states, as the key factor (Holmes 1970). Liberal perspectives tend to focus on policy initiation and advocacy, the participatory attributes of middle power, by defining states that participate actively in global issue areas like human rights, human security, peace, environment and multilateralism as middle powers (Cooper et al. 1993). Middle powers have also been seen as countries that have 
the power to assert their influence in the regional settings and have the intention enthusiastically to advocate multilateral cooperation with the countries that share similar values and purposes (Lee and Park 2017). To operationalise their intention, they require economic and/or military capacities that should be large enough to exert regional influence.

In addition, middle powers are willing to take a role of mediator based on their "positional power" from structural power vacuums in international relations. They position themselves strategically as a mediator or a broker and show their issue leadership in certain areas where they can fill in the gaps related to the relational configuration of power dynamics (Cooper 1997). Hence, "middle power states have most recently been defined by their internationalism. States that exhibit certain foreign policy behaviour are considered middle powers. Qualifying behaviour might include good 'global citizenship,' niche diplomacy, and accepting roles as mediators, followers, or staunch multilateralists" (Rudderham 2008: 2). From this perspective, status as a middle power is conferred in accordance with behaviour rather than size.

In terms of the traits and behaviour of agents, middle powers are considered neither strong nor weak in international relations. It is difficult to designate with certainty all of those specific nations which belong to this category, but it is widely accepted that a number of Western states such as Australia, Canada and Sweden fall into it. Some scholars also recognise non-Western states like Turkey, Thailand, Mexico and Argentina as middle powers (Jordaan 2013). Finally, the vanquished nations that accomplished economic development after the war, i.e., Germany and Japan, are recognised as a third categorisation of middle powers (Soeya 2006). The implication from commonalities of these states is that the status of middle power is determined comprehensively by the combination of physical capacities, international standing and reputation, relational power structure at the regional and international level, and the leadership and credentials of decision-makers.

To summarise, middle-power diplomacy was initiated to secure diplomatic autonomy and increase leverage over great powers through coalitions and network building by Canada, Australia and Nordic countries. Late-comers to the paradigm have tried to follow a similar path but have encountered limitations in clarifying relations with great powers, supplying public goods to satisfy global expectations, and aligning interests among like-minded states through issue networks (Lee and Park 2017). For a contemporary middle power to induce support from developing nations and cooperation from great powers, it should review comprehensively its capacity, resources, expertise, geopolitical traits and major issue areas, and expand mutual cooperation 
by planning thoroughly diplomatic goals, purposes and strategies. The next section addresses the history of middle-powerism in South Korea, as a policy imperative and strategic action.

\section{SOUTH KOREA'S PURSUIT OF MIDDLE-POWER DIPLOMACY}

Despite its ambiguity, the concept of "middle power" has been prominent in South Korea's diplomatic narrative, used by successive governments as a framework for their foreign policy vision and strategy (Robertson 2017). In seeking to present itself as a newly advanced country among the neighbouring strong powers in the region, South Korea needed to develop new concepts to articulate its foreign policy posture and legitimise a more proactive diplomatic role. Attributing "middle power" status to South Korea has provided a central underpinning for such efforts: the country has variously described its diplomatic character as that of a "balancer," a "hub" or indeed a "middle power" (SM Kim 2016: 2).

The Roh Moo-hyun (2003-2008) government's middle-power aspiration was expressed in the Northeast Asian Initiative, which projected South Korea's pivotal role as a "balancer" or "hub" in the region to facilitate regional cooperation in the realms of economy and security (SM Kim 2016; Chung 2008). It was primarily, however, under the Lee Myung-bak administration (2008-2013) that South Korea's self-identification as a middle power took a more explicit form (Robertson 2007; Rozman 2007; Teo 2018). A group of scholars promoted the concept to feed into national and international branding efforts at the start of the Lee presidency (SM Kim 2016). Under the overarching slogan of "Global Korea," the concept of middle power was used to support the aspiration to increase the country's international influence by enhancing its networking capacity and convening power (Jojin 2014; Green 2017). The government emphasised the functional aspect of middle-power diplomacy to legitimise South Korea's role as a convener, conciliator and proactive agendasetter in international negotiations and multilateral platform such as the 2010 G20 Seoul Summit, the High Level Forum on Aid Effectiveness in 2011 and the Nuclear Security Summit in 2012 (Teo et al. 2013; Jojin 2014; SM Kim 2016; Green 2017; Lee and Park 2017).

During the Lee administration, South Korea's middle-power identity relied mainly upon its economic strength as reflective of its unique socioeconomic development experience (Teo et al. 2013; Teo 2018). In particular, Lee's "niche diplomacy" focused on issues such as international 
development cooperation and the environment, known as "green growth promotion" (Jojin 2014; SM Kim 2016). It sought to associate its middle-power role as a bridge between developed and developing countries based on South Korea's development experience, technological advancement and growing economic influence (Teo et al. 2013; Green 2017; Teo 2018). This strategy is well matched with Cooper's arguments (1997), that traditional middle-power diplomacy tends to dwell on niche areas, focused on normative agendas of low politics (e.g., human rights, international development and the environment) due to the relatively limited range of diplomatic resources possessed by these actors when compared to those of great powers. Sohn (2015) has argued that the Lee government's focus on global, non-security issues enabled its middlepower diplomacy to avoid any significant distancing of South Korea from the United States.

Unlike the Lee government, which was eager to brand South Korea as a middle power, the Park administration (2014-2016) was reluctant to apply this label to its diplomatic posture due to its fear of provoking apprehension and/or misunderstanding in the United States and China (SM Kim 2016). Nevertheless, even though the use of middle-power language started to diminish early in Park's term, the Park administration also championed middlepower diplomacy by establishing MIKTA ${ }^{3}$ and promoting the Northeast Asia Peace and Cooperation Initiative (Lee and Park 2017). Among the public and academics in Korea and abroad, the terminology has also been used to describe South Korea's increasingly "middle" position between China and the United States (SM Kim 2016). Examples included South Korea's accession to the China-led Asian Infrastructure Investment Bank (AIIB) in March 2015, and President Park's attendance at the 70th anniversary of the end of Second World War in Beijing in September of the same year, both of which raised concerns about the future direction of the US-ROK alliance (Kim and Cha 2017).

Current President Moon Jae-in and Foreign Minister Kang Kyungwha have inherited further "homework" in terms of needing to improve relationships with China. There was more than a year of unofficial Chinese sanctions against Seoul for its decision in 2016 under the Park administration, to host the United States-operated Terminal High Altitude Area Defence (THAAD) system on its territory (Lee and Park 2017). Beijing perceived the powerful radar system accompanying the THAAD missile defence system as a threat to its own national interest (Leaf 2017). The warming of ties between the two countries followed an understanding reached over the THAAD dispute and announced in late October 2017 by both foreign ministers (Taylor 2017). 
In exchange for reassurances from South Korea that it would not acquiesce to additional United States ballistic missile defence deployments and that the country would refrain from participating in any future regional United States ballistic missile defence programme, Beijing agreed to restore normal diplomatic ties, end its unofficial economic sanctions against South Korean entities, and pursue rapprochement with Seoul (Glaser and Collins 2017).

Perhaps in deference to the diplomatic rivalry between Beijing and Washington over the Korean Peninsula, the Moon administration has not directly identified its diplomatic character as that of a "middle power," but if we consider the Moon government's "one-hundred major policy goals," which included its foreign policy goals, the overarching themes of the administration include "responsibility," "multilateralism" and "values." "Responsibility" in this context means that South Korea will fulfil its duties to foster peace and prosperity in the region (Lee 2017), which, it can be argued, is one of the characteristics of a "middle power" in the international community. Also, considering Foreign Minister Kang's previous career at the UN, it is expected that a new direction for South Korean foreign policy will focus on multilateralism with an emphasis on universal values, such as human rights, democracy, and rule of law. In this regard, although the Moon administration has not explicitly branded itself as a middle power, its de facto foreign policy strategy remains deeply wedded to middle-power diplomacy.

Yet it is in the non-traditional security sphere, and regional interpretation of middle-powerism, that Korea most displays middle-power characteristics and inclinations; in particular with reference to Southeast Asia and ASEAN. The next section, therefore, searches for Korean middle-powerism in ASEAN initiatives.

\section{SEARCHING FOR SOUTH KOREA'S MIDDLE-POWER ROLES IN ASEAN INITIATIVES}

Middle-power foreign policy behaviour is typically understood to involve adopting an internationalist perspective, actively promoting and participating in multilateralism, as well as being a bridge among nations (Lee et al. 2015; Teo 2018). Jordaan (2013: 169) argues that the preference of middle powers for internationalism and multilaterialism arises "from the inability of these states to unilaterally and single-handedly shape global outcomes in any direct manner." Multilateral settings and the liberal norms they advocate, thus provide a platform to ensure that the voices of middle powers are not ignored by the major powers (Teo et al. 2013). 
Seoul has been participating actively in regional multilateralism and is especially committed to ASEAN institution- and community-building efforts (Teo et al. 2013; Mo 2016). The ROK has also assumed a leadership role in attempted regionalisation initiatives. The inauguration of East Asia Summit (EAS) in 2005 was led by former Korean President Kim Dae-Jung's initiative on the establishment of the East Asian Vision Group (EAVG) in 1998, which in turn grew out of the experience of the 1997 financial crisis (Teo et al. 2013). Seoul has been involved in all the major ASEAN-led dialogue platforms such as the ASEAN Plus Three (APT), ARF, ASEAN Defence Minister's MeetingPlus (ADMM-Plus), East Asia Summit (EAS) (ASEAN Secretariat 2017a). In these multilateral institutions with ASEAN, South Korea has strived particularly to take on a neutral role while keeping a low profile regarding political and security issues (Teo et al. 2013).

This is in line with Jordaan's argument that middle powers do not want to "challenge or threaten the global status quo - that is, the economic and military-political 'balance' of power" (Jordaan 2013: 167). Within ASEANled multilateral institutions, other middle powers, such as, Australia, express their own voices and perspectives in EAS meetings, even on sensitive issues including the South China Sea and human trafficking in the region, while South Korea has maintained its diplomatic silence. Teo et al. (2013: 9) argue that this perceived neutrality helps Seoul in building up its network power as it can participate actively in most ASEAN initiatives, without drawing suspicion regarding its motives.

While keeping a low profile within the ASEAN networks on political and security issues, South Korea has been one of the most active and dynamic dialogue partners (DPs) of ASEAN in terms of economic and cultural affairs. Korea's dialogue ties with ASEAN originated in the late-1980s, and it achieved full Dialogue Partnership (DP) in 1991; a unique achievement for an entity which, at the time, could still itself be considered an "emerging" country (Suh 2012). South Korea was only able to join the existing states (United States, Japan, Australia, Canada, etc.) as an ASEAN dialogue partner, because of persistent lobbying from the Korean side from the early 1980s (Kim 2016).

ASEAN Member States were initially rather reluctant to establish a dialogue partnership with South Korea, due to the closer relationship of some of the members with North Korea. ASEAN countries only really started to consider South Korea as their possible dialogue partner after the success of Seoul Olympics in 1988, and they requested an annual financial contribution to ASEAN as a condition of establishing a dialogue partnership (Suh 2012). As a result of this condition, the ASEAN-ROK Cooperation Fund (AKCF) was 
established in 1990, one year before the establishment of full partnership in 1991, with an annual contribution of USD 1 million. In response to ASEAN's request for an increase in its contribution, Seoul increased the volume of the AKCF to USD 2 million per year in 1992 (Suh 2012). As a reflection of South Korea's emphasis on ASEAN, the volume of AKCF was further increased to USD 3 million per year in 2005, USD 5 million per year in 2010 and USD 7 million per year in 2015 (ASEAN Secretariat 2017a).

In particular, President Lee's "New Asia Initiative" announced in 2010, a policy promoting strong Korean engagement with all Asian countries, including with ASEAN, carved out a new direction for South Korea as its diplomatic attention had traditionally been focused solely on "the big four" of the United States, Russia, China and Japan (Teo et al. 2013). Korea's presidential office noted then that "Korea's bid to diversify its diplomatic focus [...] is inevitable due to the growing influence and importance of Asia." Although Lee (2017) argues that the Lee Myung-bak's New Asia Initiative was fundamentally a mercantilist one, viewing ASEAN as a market for South Korea to maximise economic benefits, it involved, in fact, far more comprehensive cooperation. In 2012, Korea opened a diplomatic mission to ASEAN, following in the footsteps of the United States, Japan and China (Teo et al. 2013). Korea's relations with ASEAN are also institutionalised in forums such as the APT, ARF, ADMM-Plus and EAS.

This diplomatic tradition towards ASEAN is expected to be continued, and even expanded, under President Moon. According to a report to the Presidential Office prepared by the policy planning committee, the Moon government's foreign policy is labelled as Northeast Asia Plus Community of Responsibility (NAPCOR), which has three pillars: the Northeast Asia Peace and Cooperation Initiative (NAPCI), New Nordpolitik and New Southern Policy, which is targeted at ASEAN and India (Kim 2017). Unlike the case with previous governments, the Moon government is unlikely to pressure ASEAN member states to review their ties with North Korea (Lee 2017). It is also probable that the Moon government will allocate more resources to address regional NTS threats through cooperation with ASEAN (Lee 2017).

The ROK has also pledged to contribute to ASEAN capacity-building in areas including counter-terrorism, energy security, infrastructure development and climate change (ASEAN 2017b). Korea's participation in multilateralism to resolve regional problems, as well as its concentrated contributions to ASEAN, clearly boost its middle-power status. Yet while it may have a role in the overall ASEAN architecture, Seoul remains absent from Southeast Asia's geostrategic calculus, mainly due to the United States and China rivalry in 
the region. ASEAN has long sought to prevent a great power conflict which would force its members to choose sides between China and the United States. For most ASEAN member states, it is crucial to continue expanding trade and investment ties to China, on the one hand, while maintaining robust military cooperation with the United States as a hedging strategy on the other (Morton 2016). The ongoing disputes in South China Sea, is one of many current and potential flash points in the race between two strategic paradigms, which can be aptly described as a clash between the United States "Indo-Pacific region" and China's "One Belt, One Road (OBOR)" (Lee and Bong 2016).

The clash between United States and China has put South Korea in a difficult strategic dilemma as a middle power which shares enormous security and economic interests with both parties of the dispute (Lee and Bong 2016). In 2017, United States, Japan and Australia issued jointly a statement that included a paragraph demanding that China and the Philippines abide by the 2016 arbitral ruling on the South China Sea, although one of China's goals at the 31st ASEAN Summit in Manila was to downplay the topic (Gao 2017). Meanwhile, despite United States lobbying, South Korea has avoided taking public sides in the dispute beyond maintaining its basic position of respect for mainstream international maritime law and freedom of navigation (Lee and Bong 2016).

Thus, this paper argues that Korea's strategic role as a middle power in the region has been limited due to the United States and China geopolitical rivalry, which makes it impossible for Seoul to focus on participating in and promoting cooperation among the middle powers to seek pragmatic means to keep the tension in the region under control. Nevertheless, in fields outside the traditional strategic and security discourse, South Korea has been playing, and has tremendous capacity to play further, a much more significant role in Southeast Asia. The next section, therefore, assesses the potential for Korean middle-powerism in ASEAN beyond the narrow parameters of power political analysis.

\section{ASEAN OPPORTUNITIES FOR MIDDLE-POWER ACTIVISM BY THE ROK}

One of the most recognised features of contemporary middle-power activism is so-called "niche diplomacy" as middle-power states find specific issue areas that are not and cannot be dictated by great powers and concentrate their full efforts on it to take relative advantage (Cooper 1997). Although, 
as mentioned above, former Australian Foreign Minister, Gareth Evans, was major proponent of the concept, newly developed nations such as South Korea have especially favoured this strategy in order to bolster their international confidence and advance their international reputation (Evans 2012). If we track the expenditure of AKCF since its creation, we can identify specific issue areas that South Korea has been actively engaged with ASEAN through "niche diplomacy."

As seen in Figure 1, AKCF has been focused on the field of ASEAN's socio-cultural community (ASCC), such as education, environment and culture. People-to-people exchanges represent the largest segment, with education the joint-second largest, reflecting the ROK's focus on human capital, education and training, and knowledge transfer in both its own development policy-making, and its niche diplomacy (Howe 2017). These are followed by other humancentred areas of the environment and governance. Only then does trade make an appearance, just ahead of agriculture - hardly reflective of a mercantilist perspective. Such a human-centred perspective also makes partnering with the ROK more appealing than traditional international engagement at the level of state to state engagement, which can have hierarchical or even neo-imperial undertones.

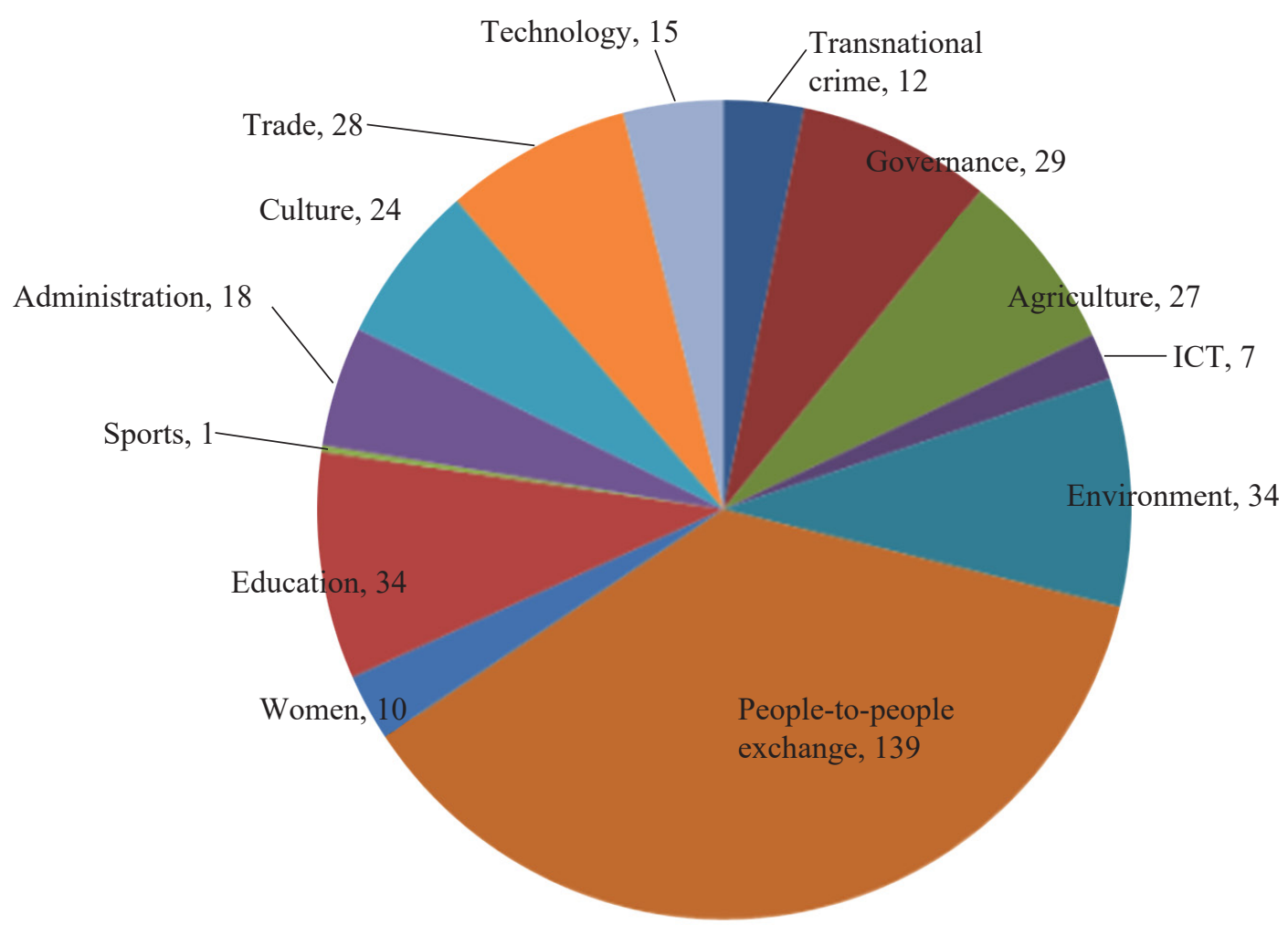

Figure 1: Number of the AKCF funded projects by sectors (1990-2017). Source: ASEAN Secretariat (2017a). 
The ASEAN-ROK Environment Cooperation Programme (AKECOP), which aims to restore degraded forest ecosystems around the region, is one of the AKCF's flagship projects. At the first ASEAN-ROK Summit in 1997, both sides identified the environment as one of the priorities of cooperation and promised to implement relevant projects. Since 2000, the AKECOP has been operated for forest restoration and mitigating the disastrous impact of climaterelated disasters such as cyclones (ASEAN Secretariat 2017b). AKECOP has become the longest running environmental cooperation project among ASEAN's DPs, and the output and outcome of the AKECOP have been well shared with ASEAN through its sponsoring ASEAN body, the ASEAN Working Group on Nature Conservation and Biodiversity (AWGNCB). ${ }^{4}$

The ASEAN-ROK Film Leaders Incubator Project (FLY) is another flagship project of the AKCF. This project has been implemented by Busan Film Commission, organiser of the Busan International Film Festival since 2012, with the aim of discovering young film talent in ASEAN, nurturing the ASEAN film industry and establishing a stable filmmaking infrastructure that will contribute to the diversification of Asian film (Suh 2017). So far, the FLY project has made a number of noteworthy achievements in enhancing ASEANROK cultural cooperation such as the establishment of the Busan Asian Film School to cultivate young talent in the international film business. FLY Alumni are emerging as leading figures of the next generation in the film industry and sharing knowledge and experience with younger generations. ${ }^{5}$ ASEAN (2017b) has noted in particular, that an ASEAN-ROK Film Community has been established through exchanges between Southeast Asian and Korean film leaders. It is the only ASEAN-DP cooperation programme in film, which has made a significant contribution to the ASEAN member states, especially those countries that are in their early stage of film industry development. ${ }^{6}$ Given the ubiquitous impact of the Korean Wave or hallyu in Southeast Asia, this is a natural area of cooperation where the ROK can further establish its middlepower credentials in the region.

In another first for a dialogue partner of ASEAN, in 2017 South Korea established the ASEAN Culture House in Busan, following up on the agreement made at the ASEAN-ROK Commemorative Summit in 2014. Current Korean Foreign Minister Kang emphasised that the Culture House is expected to serve as a venue to boost two-way people-to-people and cultural exchanges between the ROK and ASEAN (Lee and Kim 2017). This new institutional effort demonstrates South Korea's activism in utilising its soft power approach with ASEAN. 
As seen by these two flagship projects of AKCF, and the establishment of the ASEAN Culture House, South Korea has played as a "bridging role," focusing on issue-specific cooperation activities through sharing its own experiences with ASEAN. This role profits from South Korea's positional advantage or "in-betweeness" in the regional hierarchy between the North, ASEAN's major DPs and the South, ASEAN. Unlike other middle powers in the region, (for instance Australia), South Korea has remained neutral, or silent, on politically sensitive issues, such as the South China Sea, but very active in niche diplomacy using soft power tactics. South Korea's middlepower strategy toward ASEAN has been regarded as very successful since it is differentiated from the engagement of other DPs of ASEAN and makes South Korea more approachable to ASEAN member states. ${ }^{7}$

South Korea also engages in non-traditional middle-power activism with ASEAN member countries through another avenue wherein it commands high reputational resources in the region; that of development and development cooperation. The ROK enacted a Framework Act on International Development Cooperation (Framework Act) and a Presidential Decree which came into force in July 2010, in order to lay the basis for a more effective official development assistance (ODA) system. This was followed, in October 2010, at the 7th meeting of the Committee for International Development Cooperation (CIDC) by the Strategic Plan for International Development Cooperation (Strategic Plan). In 2015, in accordance with the Framework Act and the Strategic Plan, the Korean government formulated Country Partnership Strategies (CPS) for 24 priority partner countries in order to maximise synergy effects and to improve ODA effectiveness through strategic concentration. The largest geographical concentration of priority countries was in Asia (11 countries), with six ASEAN Member states: the CLMV countries (Cambodia, Laos, Myanmar and Vietnam) as well as the Philippines and Indonesia (ODA Korea).

Focus sectors with ASEAN priority partner countries reflect not only mercantilist and infrastructure development considerations, but also those related to more humanitarian development issues including: Cambodia (Rural and Agriculture Development / Green Energy / Human Resource Development / Health and Medical Care), Laos (Water Resources and Electricity / Human Resource Development/Health and Medical Care), Myanmar (Governance and Rural Development) Vietnam (Environment and Green Growth / Vocational Training), the Philippines (Agriculture and Water Resources / Health and Medical Care), and Indonesia (Governance / Environment Protection / Water management) (ODA Korea). 
While mercantilism, the exploits of South Korean companies, and support for macro-economic development projects may generate negative publicity, and even be counter-productive ${ }^{8}$ (Howe 2013; Kalinowski and Park 2016; Watson 2013), development assistance in these people-centred areas, and other humanitarian activities by the ROK have been overwhelmingly positively received (OECD DAC 2018). Especially, in terms of humanitarian assistance, South Korea has been praised by the OECD DAC and the UN International Search and Rescue Advisory Group (UN INSARAG) for its serious investment in high-performing emergency response capacities through the establishment of the Korean Disaster Relief Team (KDRT) (OECD DAC 2018; Yoon 2016). Since its creation in 2007, the relief team has been deployed in nine emergencies including four emergencies in the region, namely cyclone Nargis in Myanmar in 2008, earthquakes in Indonesia in 2009, typhoon Haiyan in the Philippines in 2013, and the dam collapse in Laos in 2018.

As has been demonstrated in this section of the paper, South Korea has actively engaged with ASEAN using the different modalities of (development) cooperation, focusing on "niche areas" within which the ROK has relative advantages. In order to further enhance South Korea's middle-powerism in the region, South Korea should move beyond its "bridging role" towards supporting humanitarian norm-building within ASEAN. In this context, the following section provides policy prescription for South Korea's future engagement with and in ASEAN that could enhance its middle-powerism.

\section{POLICY PRESCRIPTION FOR FUTURE ENGAGEMENT WITH AND IN ASEAN BY THE ROK}

As mentioned above, President Moon Jae-in announced Korea's future initiatives for ASEAN in the "New Southern Policy" in 2017. President Moon (2017) noted in his piece for Project Syndicate that the initiative was guided by the "three Ps" of People, Prosperity and Peace and he affirmed that he will pursue "people-centred diplomacy" toward ASEAN to realise this vision. The next step for South Korea in order to translate that rhetoric into reality, is to expand its middle-power role for rule-based regional order while engaging more deeply with ASEAN as an institution, rather than with individual countries in the region. The justifications for this range from the practical, since many regional structures in the Asia are built on an ASEAN foundation, to the symbolic, since closer ties with ASEAN would indicate a stronger commitment to Southeast Asia as a whole. 
In order to strengthen South Korea's middle-power role toward ASEAN and to realise "people-centred diplomacy" toward ASEAN, this paper recommends that South Korea should deepen and broaden its engagement with the humanitarian norm-promoting organisations within ASEAN, especially the ASEAN Intergovernmental Commission of Human Rights (hereafter, AICHR) and the ASEAN Coordinating Centre for Humanitarian Assistance on disaster management (hereafter, AHA Centre).

The AICHR was inaugurated in October 2009 as a consultative body of ASEAN on human rights protection in accordance with Article 14 of the ASEAN Charter (Hanung et al. 2018). Its main responsibility is to promote regional cooperation on human rights. So far, it has achieved progress in strengthening the framework for human rights cooperation within ASEAN. The adoption of the ASEAN Human Rights Declaration in 2012 created a momentum for ASEAN to set up a more comprehensive framework for human rights cooperation and provided additional value to international norms and standards of human rights (Wahyuningrum 2014). The AICHR has, however, been mired in endless controversies mostly due to the challenges related to ASEAN's rule of non-interference (Caballero-Anthony 2012). ASEAN has a strict tradition (known as the ASEAN Way) of avoiding criticism of member states internal affairs, whether by other members, or by institutions of ASEAN, and particularly those internal affairs directly related to the issue of human rights. Therefore, it has not systematically addressed any human rights cases that have been submitted by civil society organisations, including the human rights violations against the Rohingya (Forum-Asia 2018).

The actual function of the AICHR is, then, reduced to an educational and awareness-building role on human rights, rather than tackling the problem and finding the solution. Although South Korea has recognised AICHR's on-going limitations, it has been supportive of the implementation of AICHR's Work Plan 2016-2020 by responding to AICHR's request for sponsorship related to specific projects and events. ${ }^{9}$ In Phnom Penh, Cambodia, in 2016, South Korea supported the AICHR regional workshop on strengthening national plans of action on trafficking in persons to ensure effective implementation of the ASEAN Convention against Trafficking in Persons, Especially Women and Children (ACTIP) and ASEAN Plan of Action against Trafficking in Persons, Especially Women and Children (APA) (AICHR). In 2017, South Korea also supported the AICHR Workshop in Yangon, Myanmar on a Rights-based Approach to regional management strategy for an effective environmental impact assessment. While recognising that South Korea's engagement with the AICHR is in its very early stage, nonetheless, this paper recommends that 
the ROK should engage further with the AICHR in order to restore and uphold the principle of democracy and rule of law enshrined in the ASEAN Charter, and ensure the implementation of these principles in the ASEAN member states. South Korea should consider supporting institutional development of the AICHR through triangular cooperation with like-minded partners, such as the United States and Australia. Especially, 2019 will mark the ten-year anniversary of the AICHR. Like-minded partners should cooperate particularly with Thailand, the chairing country of ASEAN in 2019, to make special efforts to the functioning of the AICHR.

In order to demonstrate issue leadership as a regional middle power, South Korea should expand its regional role regarding NTS issues, including humanitarian assistance and disaster relief (HADR). The ROK has responded to natural disasters and health challenges on an individual case-by-case basis in Southeast Asia, including in November 2013 when South Korea provided the largest contingent of forces for relief and reconstruction efforts in the Philippines after the devastation wrought by Typhoon Haiyan (Howe 2017: 258). Furthermore, the ROK forces were committed to the mission for far longer than those of any other contributing nation - two full six-month tours of duty rather than just helping with the emergency relief mission in the immediate aftermath of the disaster. ${ }^{10}$ Yet, as reviewed above, contemporary middlepowerism reflects a greater need for internationalism and multinationalism.

To fulfil this expected role, South Korea should consider strengthening its partnership with the ASEAN Coordinating Centre for Humanitarian Assistance on disaster management (AHA Centre). South Korea's engagement with the AHA Centre has been limited to capacity development at the project level. So far, only one project, namely, the ASEAN Science-based Disaster Management Platform (ASDMP) project, was implemented from January 2016 to December 2017, supported by the AKCF. ${ }^{11}$ The ASDMP project was initiated by the former President Park Geun-hye during the 2014 ASEAN-ROK Commemorative Summit in Busan. President Park emphasised the need for cooperation in climate change and disaster response in the ASEAN region, and announced a landmark commitment for South Korea to help improve disaster management in the ASEAN region through its strengths in the utilisation of Information and Communications Technology (ICT) for disaster response. ${ }^{12}$

This spurred the initiation of the ASDMP project in collaboration with APEC Climate Centre in South Korea and the AHA Centre. As the results of the ASDMP project, the disaster management web platform had been co-developed and training courses for staff of the AHA Centre had been offered. While the AHA Centre is focused on addressing ASEAN's needs, 
the framework of cooperation could potentially be extended to facilitate ASEAN-ROK mutual support in the event of contingencies. Also, ASEAN and ROK should build closer cooperation between the AHA Centre and the ROK-initiated Disaster Management Network in the implementation of the comprehensive disaster management cooperation plan. Especially, the Korea International Cooperation Agency (KOICA) should share its experience of operating the KDRT to the AHA Centre. Since the AHA Centre is responsible for the deployment of the ASEAN-Emergency Response and Assessment Team (ASEAN-ERAT) in the disaster affected ASEAN Member States, and have deployed more than twenty emergency missions (AHA Centre 2018), there is a room to initiate cooperation on disaster response activities between the KDRT and the ASEAN-ERAT.

Furthermore, the South Korean government should strengthen cooperation to jointly address other NTS issues with ASEAN. Greater cooperation in NTS challenges was articulated in two Joint Statements of the ASEAN-ROK Commemorative Summits on the 20th and 25th Anniversary of the ASEAN-ROK Dialogue Relations (ASEAN 2009; ASEAN 2014). And, both sides identified eight NTS areas to strengthen cooperation in the ASEAN-ROK Plan of Action 2016-2020, namely terrorism, trafficking in persons, arms smuggling, sea piracy, money laundering, illicit drug trafficking, international economic crime and cybercrime through the existing dialogue mechanisms (ASEAN Secretariat 2016). There have yet to be, however, any supporting initiatives to realise the said agreements. In this regard, a master plan or strategy paper needs to be co-developed as part of the "New Southern Policy," so that South Korea could assist ASEAN in the implementation of harmonising norms and regulations among the countries of the region in these NTS issues. Korea's own experience could be important in helping shape institutional standards that would be the bases of these regulations.

\section{CONCLUSION}

For South Korea, the most prominent national role over the last four administrations has been the conceptualisation of itself as a middle power. While there is no agreement on what constitutes a middle power (Robertson 2017), there has been a growing consensus that South Korea's national role has evolved to conform to most interpretations of what constitutes a middle power in order to justify its greater involvement at the regional and global levels (Karim 2018). Nonetheless, this paper argues that South Korea's middle 
power diplomacy toward ASEAN seems incomplete, narrowly portrayed itself as an advocate of developmentalism and a bridge-builder focusing on "niche areas" within which the ROK has relative advantages. In order to further enhance South Korea's middle-powerism in the region and to realise "peoplecentred diplomacy" toward ASEAN, as indicated in President Moon's New Southern Policy, this paper recommends that South Korea should deepen its engagement with humanitarian norm-building processes within ASEAN and realise its regional role regarding NTS issues.

So far, the dynamics of alignments with ASEAN have been analysed mostly from the perspective of great power politics, which highlighted the reactive or, at best, ambivalent nature of middle powers, such as Australia and Japan. Since this paper reveals the challenges and future opportunities of South Korea's middle-powerism toward ASEAN, it hopes to contribute to the existing discussion about middle-power engagement with ASEAN.

The year 2019 marks the 30th anniversary of the dialogue relations between ASEAN and South Korea that will add momentum to advancing the partnership, and will also look forward to activities to commemorate this milestone. South Korea should project itself not just as the follower of its strategic partners, the United States and China, but as a country deeply engaged with ASEAN as a genuine "bridge-builder" in the region.

\section{NOTES}

* Brendan Howe is Associate Dean and Professor of the Graduate School of International Studies, Ewha Womans University, South Korea, where he has worked since 2001. His ongoing research agendas focus on traditional and non-traditional security in East Asia, human security, democratic governance, public diplomacy and post-crisis development. His major recent works include Regional Cooperation for Peace and Development: Japan and Korea in Southeast Asia (2018); National Security, Statecentricity, and Governance in East Asia (2017); Peacekeeping in the Asia-Pacific (2016); Democratic Governance in Northeast Asia (2015); Post-conflict Development in East Asia (2014); and The Protection and Promotion of Human Security in East Asia (2013).

** Min Joung Park is a PhD candidate in the Graduate School of International Studies at Ewha Womans University, South Korea. She served as a policy specialist in Development Policy Division and African Division at the Ministry of Foreign Affairs, Republic of Korea. She also worked as a Programme Manager of the ASEAN-ROK Programme Management Team (AKPMT) of the ASEAN Secretariat. Her research interests involve Korea's foreign aid policy, ASEAN-Korea relations and middle power diplomacy. 
1 North Korea had expressed its desire to participate in the ARF in November1993, before the creation of the ARF in July 1994 (Kim 1998). Seoul had taken a positive position toward North Korea's participation in the ARF, especially in association with President Kim Dae-jung (1998-2003)'s Sunshine Policy (Lee 2000).

2 SM Kim (2016: 7) argues that earlier diplomatic rows over Roh's "northeast Asian balancer" initiative had made South Korean policy-makers more sensitive about using terms relating to middle powers such as "balancing," "hedging" or "equidistance."

3 MIKTA is an innovative middle-power partnership that brings together Mexico, Indonesia, South Korea, Turkey and Australia in order to bridge divides in the multilateral system and build consensus on complex issues.

4 Srisai, S., interviewed by Park, M. J., Jakarta, 30 June 2017.

5 Choi, Y., interviewed by Park, M. J., Jakarta, 15 November 2017.

6 Tan, J. G. T., interviewed by Park, M. J., Jakarta, 23 January 2018.

7 Manalu, C., interviewed by Park, M. J., Jakarta, 25 October 2017.

8 South Korean civic groups, such as the People's Solidarity for Participatory Democracy (2018) and the People's Initiative for Development Alternatives (2018), view the collapse of the Xe Pian/Xe Nam Noy hydropower dam in southeast Laos in July 2018 as proof that South Korea's development cooperation projects, especially bilateral loans from the Economic Development Cooperation Fund (EDCF), driven by mercantilism, could not create meaningful development outcomes, but rather endanger local people's lives. They argue that the Ministry of Strategy and Finance (MOSF) of Korea extensively advertised this project as a new model of financial conglomerates combining "aid" and "export," but the government did not examine safeguard measures including environmental impact assessment and compliance mechanisms that are required for infrastructure projects.

9 Wana, E., interviewed by Park, M. J., Jakarta, 23 October 2017.

10 Arcala Hall, R., interviewed by Howe, B., Seoul, 30 May 2016.

11 Kamal, A., interviewed by Park, M. J., Jakarta, 4 December 2017.

12 Jung, H-s., interviewed by Park, M. J., Jakarta, 4 December 2017.

\section{REFERENCES}

AHA Centre. 2018. Factsheets on ASEAN-ERAT. ASEAN Coordinating Centre for Humanitarian Assistance on Disaster Management. https://ahacentre.org/wpcontent/uploads/2018/01/DIGITAL-Version-FACTSHEETS-ASEAN-ERAT.pdf (accessed 5 December 2018).

ASEAN Secretariat. 2009. Joint statement of the ASEAN-ROK commemorative summit on the 20th anniversary of the ASEAN-ROK dialogue relations. https://www.asean. org/storage/images/archive/PR-AK-Commemorative-Summit.pdf (accessed 5 December 2018).

2014. Joint statement of the ASEAN- ROK commemorative summit on the 25th anniversary of the ASEAN-ROK dialogue relations. https:/asean.org/asean-rokjoint-statement-from-the-country-coordinator-indonesia-on-the-recently-heldasean-rok-commemorative-summit-on-12-december-2014-in-busan-republic-ofkorea/ (accessed 5 December 2018). 
2016. ASEAN-ROK plan of action to implement the joint declaration on strategic partnership for peace and prosperity (2016-2020). http://asean.org/storage/2012/05/ ASEAN-ROK-POA-2016-2020-FINAL.pdf (accessed 12 August 2018).

2017a. New Framework for the ASEAN-ROK Cooperation Fund (AKCF) 20172020. ASEAN.

. 2017b. Overview of ASEAN-Republic of Korea Dialogue Relations. http://www. asean.org (accessed 12 May 2018).

ASEAN Intergovernmental Commission on Human Rights. 2017. Press release: ASEAN explores framework for an effective environment impact assessment to ensure sustainable development, 1 November. http://aichr.org/category/press-release/ page/3/ (accessed 10 July 2018).

ASEAN Regional Forum. 2017. Chairman's statement of the 24th ASEAN regional forum, Philippines, 7 August. http://www.asean2017.ph/wp-content/uploads/7.ChairmansStatement-of-the-24th-ARF-FINAL.pdf (assessed 7 August 2018). 2018. Chairman's statement of the 25th ASEAN Regional Forum, Singapore, 4 August. http://asean.org/storage/2018/08/Final_Chairmans_Statement_of_ the 25th_ARF.pdf (accessed 7 August 2018).

Asian Forum for Human Rights and Development (Forum-Asia). 2018. ASEAN should uphold the principle of democracy and strengthen its human rights institutions. Forum-Asia statement, 15 November. https://www.forum-asia.org/?p=27689 (accessed 2 December 2018).

Caballero-Anthony, M. 2012. The responsibility to protect in Southeast Asia: Opening up spaces for advancing human security. The Pacific Review 23 (1): 113-134, https://doi.org/10.1080/09512748.2011.632971.

Chung, I. 2008. The progress of Korea's FTA policy in the context of Northeast Asian Economic Cooperation. In Political economy of Northeast Asian regionalism: Political conflict and economic integration, eds. Park, J., Pempel, T. J. and Roland, G., 56-66. Cheltenham: Edward Elgar.

Cooper, A. F. 1997. Niche diplomacy: Middle powers after the Cold War. New York: St. Martin's Press.

Cooper, A. F., Higgott, R. A. and Nossal, K. R. 1993. Relocating middle powers: Australia and Canada in a changing world order. Vancouver: University of British Columbia Press.

Evans, G. 2012. No power? No influence? Australia's middle power diplomacy in the Asian Century. 2012 Charteris Lecture to the Australian Institute of International Affairs (AIIA), New South Wales Branch, Sydney, 6 June. http://www.gevans.org/ speeches/speech472.html (accessed 15 August 2018).

Gao, C. 2017. US, Australia, Japan jointly challenge China on South China Sea issue. The Diplomat, 9 August. https://thediplomat.com/2017/08/us-australia-japan-jointlychallenge-china-on-south-china-sea-issue/ (accessed 15 August 2018).

Glaser, B. S. and Collins, L. 2017. China's rapprochement with South Korea. Foreign Affairs, 7 November. https://www.foreignaffairs.com/articles/china/2017-11-07/ chinas-rapprochement-south-korea (accessed 15 August 2018). 
Green, M. J. 2017. Korean middle power diplomacy and Asia's emerging multilateral architecture. In The Korean pivot: The study of South Korea as a global power, eds. Cha, V. D. and Dumond, M., 17-34. Washington: Center for Strategic and International Studies.

Hanung, C. D., Ginting M. S. and Judhistari, R. A. 2018. Resonable doubt: The journey within. Report on the Annual Performance of the ASEAN Human Rights Mechanisms in 2017, Forum-Asia, Bangkok. https:/www.forum-asia.org/uploads/wp/2018/11/ ASEAN-Human-Rights-Institution-Performance-Report-2017-Final-2-1.pdf (accessed 3 December 2018).

Heo, U. and Roehrig, T. 2014. South Korea's rise: Economic development. Power, and foreign relations. Cambridge: Cambridge University Press.

Holbraad, C. 1971. The role of middle powers. Cooperation and Conflict 6 (1): 77-90, https://doi.org/10.1177/001083677100600108.

Holmes, J. 1967. Canada's role in the United Nations. Air University Review, May-June. 1970. Is there a future for middlepowermanship? In The better part of valour: Essays on Canadian diplomacy, ed. Holmes, J., 18-49. Toronto: The Carleton Library.

Howe, B. 2013. The protection and promotion of human security in East Asia. Basingstoke: Palgrave Macmillan.

2017. Korea's role for peacebuilding and development in Asia. Asian Journal of Peacebuilding 5 (2): 243-266.

Hundt, D. 2012. Middle powers and the building of regional order: Australia and South Korea compared. In Asian responses to the global financial crisis: The impact of regionalism and the role of the G2, eds. Park, J., Pempel T. J. and Xiao, G., 193211. Cheltenham: Edward Elgar.

Jackson, V. 2015. The South China Sea needs South Korea. The Diplomat, 24 June. https://thediplomat.com/2018/05/south-koreas-free-and-open-indo-pacificdilemma/ (accessed 2 December 2018).

Jojin, J. 2014. Becoming and being a middle power: Exploring a new dimension of South Korea's foreign policy. China Report 50 (4): 325-341, https://doi. org/10.1177/0009445514549274.

Jordaan, E. 2013. The concept of a middle power in international relations: Distinguishing between emerging and traditional middle powers. South African Journal of Political Studies 30 (1): 165-181, http://doi.org/10.1080/0258934032000147282.

Kalinowski, T. and Cho, H. 2012. Korea's search for a global role between hard economic interests and soft power. European Journal of Development Research 24: 242-260, https://doi.org/10.1057/ejdr.2012.7.

Kalinowski, T. and Park, M. J. 2016. South Korean development cooperation in Africa: The legacy of a developmental state. Africa Spectrum 52 (3): 61-75.

Karim, M. F. 2018. Middle power, status-seeking and role conceptions: The cases of Indonesia and South Korea. Australian Journal of International Affairs 72 (4): 343-363, https://doi.org/10.1080/10357718.2018.1443428.

Kim, E. and Cha, V. 2017. Between a rock and a hard place: South Korea's strategic dilemmas with China and the United States. Asia Policy 21: 101-121. http://www.nbr.org/ publications/asia_policy/free/120516/AsiaPolicy21_Kim_Cha_January2016.pdf (accessed 12 June 2018). 
Kim, H. J. 2016. Han-Asean daewhagwangyewa Asean gyubeom: 1980 nyeondae choban oegyo munseo bunseog jungsim-eulo [Korea-ASEAN dialogue partnership and ASEAN norms: An analysis of diplomatic history in the early 1980s]. Dongnam Asia Yeongu [The Southeast Asian review] 22 (1): 39-76.

Kim, J. 2017. South Korea's free and open Indo-Pacific dilemma. The Diplomat, 27 April. https://thediplomat.com/2018/05/south-koreas-free-and-open-indo-pacificdilemma/ (accessed 15 August 2018).

Kim, S. H. 1998. The role of the ARF and the Korean peninsula. The Journal of East Asian Affairs 12 (2): 506-528.

Kim, S. M. 2016. South Korea's middle-power diplomacy: Changes and challenges. London: Chatham House.

Leaf, P. J. 2017. America and Japan must respond collectively to China's bullying. The National Interest, 29 November. https:/nationalinterest.org/feature/america-japanmust-respond-collectively-chinas-bullying-23423 (accessed 15 April 2017).

Lee, C. H. 2000. Bughun ASEAN jiyeoganbopoleom gaib uimi [Significance of joining North Korea in the ARF]. Joongang Ilbo, 28 July. https://news.joins.com/ article/3950392 (accessed 4 December 2018).

Lee, J. 2017. 2017 Asean anbopoleom gyeolsan: Hanmijung-ui seongjeogpyo [The closing of ASEAN Regional Forum (ARF) in 2017: Report cards of South Korea, the US and China]. AIPS Issue Brief 24. Seoul: The Asan Institute for Policy Studies (AIPS). $\mathrm{http}$ //asaninst.org/contents/2017년-아세안안보포럼-arf-결산-한미중의-성적표/\#9 (accessed 14 April 2018).

Lee, J. and Bong, Y. D. 2016. South Korea's strategic distance from the South China Sea. In The South China Sea: Middle power perspectives, eds. Taylor, B. et al., 12-17. Canberra: Strategic and Defence Studies Centre, Australian National University.

Lee, K. M. and Kim, Y. S. 2017. ASEAN Culture House opens in Busan. Korea.net, 6 September. http://www.korea.net/NewsFocus/policies/view?articleId=148983 (accessed 20 May 2018).

Lee, S., et al. 2015. Middle power in action: The evolving nature of diplomacy in the age of multilateralism. Singapore: East Asia Institute.

Lee, S. and Park, C. Y. 2017. Korea's middle power diplomacy for human security: A global and regional approach. Journal of International and Area Studies 24 (1): 21-44.

Ministry of Trade, Industry and Energy (MOTIE). 2017. ASEAN became Korea's second largest trading partner. MOTIE press release, 31 May. http://english.motie. go.kr/en/tp/ftaeconomiccooperration/bbs/bbsView.do?bbs_seq_n $=562 \& b b s$ cd_n=2\&view_type_v=TOPIC\&\&currentPage $=1 \&$ search_key_n $=\&$ search_val_ $\mathrm{v}=\&$ cate $\mathrm{n}=4$ (accessed 15 August 2018).

Mo, J. 2016. South Korea's middle power diplomacy: A case of growing compatibility between regional and global roles. International Journal 71 (4): 587-607, https://doi.org/10.1177/0020702016686380.

Moon, J. 2017. Toward a people-centered ASEAN community. Project Syndicate, 11 November. https://www.project-syndicate.org/commentary/korea-aseancooperation-at-50-by-jae-in-moon-2017-11?barrier=accesspaylog (accessed 10 July 2018). 
Morton, K. 2016. China's ambition in the South China Sea: Is a legitimate maritime order possible? International Affairs 92 (4): 909-940.

Neack, L. 1992. Empirical observations on 'middle state' behaviour at the start of a new international system. Pacific Focus 7 (1): 5-21, https://doi. $\operatorname{org} / 10.1111 / \mathrm{j} .1976-5118.1992 . t b 00139 . x$.

Organization for Economic Co-operation and Development (OECD). 2016. DAC member profile: Korea 2016. http://www.oecd.org/dac/korea.htm (accessed 10 April 2018). . 2018. OECD development cooperation peer review: Korea 2018. https://read. oecd-ilibrary.org/development/oecd-development-co-operation-peer-reviewskorea-2018_9789264288829-en\#page1 (accessed 12 August 2018).

People's Initiative for Development Alternatives (PIDA). 2018. A statement on the tragic collapse of a dam in Laos. PIDA press release, $30 \mathrm{July} . \mathrm{http}: / /$ pida.or.kr/ voice/?idx=1077487\&bmode=view (accessed 10 August 2018).

People's Solidarity for Participatory Democracy. 2018. Joint Statement on the Xe PianXe Nam Noy dam project which takes the whole life of the people of Laos, Seoul, 9 August. http://www.peoplepower21.org/index.php?mid=English\&document srl=1577704\&listStyle=list (accessed 10 August 2018).

Pinkston, D. A. and Work, C. 2015. Park Geun-hye's visit and the US-ROK alliance. The Diplomat, 26 October. https://thediplomat.com/2015/10/park-geun-hyes-visit-andthe-us-rok-alliance/ (accessed 10 April 2018).

Pratt, C. 1990. Middle power internationalism: The North-South dimension. Montreal: McGill-Queen's University Press.

Robertson, J. 2007. South Korea as a middle power: Capacity, behaviour, and now opportunity. International Journal of Korean Unification Studies 16 (1).

2017. Continuity in South Korean foreign policy. KEI Academic Paper Series, Korea Economic Institute of America, Washington, DC. http://keia.org/sites/ default/files/publications/kei_aps_robertson_170414.pdf (accessed 14 April 2018).

Roehrig, T. 2015. Caught in the middle: South Korea and the South China Sea arbitration decision. Asian Yearbook of International Law 21: 96-120.

Rozman, G. 2007. South Korea and Sino-Japanese rivalry: A middle power's options within the East Asia Core Triangle. Pacific Review 20 (2): 197-220, https://doi.org/10.1080/09512740701306840.

Rudderham, M. A. 2008. Middle power pull: Can middle powers use public diplomacy to ameliorate the image of the West? York Centre for International Security Studies Working Paper 46, February. http://yciss.info.yorku.ca/files/2012/06/WP46Rudderham.pdf (accessed 12 April 2018).

Shin, H. 2017. ASEAN culture house to open in Busan. Korea Herald, 31 August. http://www.koreaherald.com/view.php? $\mathrm{ud}=20170831000574$ (accessed 15 April 2018).

Soeya, Y. 2006. Ilbonui Middle Power Eoigyo: Jeonhu Inboni Seontaekgwa Gusang [Japans Diplomacy with "Middle Nations": Japans Choice and Plan after WW]. Transl. Park, C. H., Yoon, S. and Lee, N. O. Seoul: Oreum. 
Sohn, Y. 2016. Seoron: Hangukui junggyounguk eoigyo, gaenyumgwa yeoksa [Introduction: Concept and history of Korea's middle power diplomacy]. In Hangukui junggyounguk eoigyo: Yeoksa, yiron, shilje [Korea's middle power diplomacy: History, theory, and reality], eds. Yul, S., Kim, S. and Lee, S., 1-27. Seoul: Myongin Munhwasa.

. 2017. President Moon unveils NEW Southern Policy for ASEAN. Korea.net, 10 November. http://korea.net/NewsFocus/policies/view?articleId=151092 (accessed 20 April 2018).

Suh, J. 2012. Hangug-ui Dae Asean Oegyo [The Republic of Korea's diplomacy toward ASEAN]. Dongnam Asia Yeongu [The Southeast Asian review] 22 (1): 279-308. . 2017. ASEAN-ROK fund a catalyst for progress. Myanmar Times, 21 September. https://www.mmtimes.com/news/asean-rok-fund-catalyst-progress.html (accessed 15 February 2018).

Taylor, A. 2017. South Korea and China move to normalize relations after THADD dispute. WashingtonPost, 31 October. https://www.washingtonpost.com/world/south-koreaand-china-move-to-normalize-relations-after-thaad-conflict/2017/10/31/60f2bad8bde0-11e7-af84-d3e2ee4b2af1_story.html?utm_term=.b7f7ddccce36 (accessed 15 June 2018).

Tellies, A. J. et al. 2000. Measuring power in the post-industrial Age. Santa Monica: RAND.

Teo, S. 2018. Middle Power identities of Australia and South Korea: Comparing the Kevin Rudd/Julia Gillard and Lee Myung-bak administration. The Pacific Review 31 (2): 221-239, https://doi.org/10.1080/09512748.2017.1371210.

Teo, S., Singh, B. and Tan, S. S. 2013. South Korea's middle-power engagement initiatives: Perspectives from Southeast Asia. RSIS Working Paper no. 265. https://files.ethz.ch/ isn/174582/WP265South\%20Korea's\%20Power\%20Engagement\%20Initiatives. pdf (accessed 24 March 2018).

Vom Haua, M. Scott, J. and Hulme, D. 2012. Beyond the BRICs: Alternative strategies of influence in the global politics of development. European Journal of Development Research 24 (2): 187-204, https://doi.org/10.1057/ejdr.2012.6.

Wahyuningrum, Y. 2014. The ASEAN intergovernmental commission on human rights: Origins, evolution and the way forward. Stockholm: International Institute for Democracy and Electoral Assistance.

Watson, I. 2011. Global Korea: Foreign aid and national interest in an age of globalization. Asian Journal of Political Science 20 (3), https://doi.org/10.1080/13569775.2011. 552688.

2013. Beyond the aid trap for emerging donors: Private and public partnership in South Korea's Official Development Assistance (ODA) strategy. Journal of Comparative Asian Development 12 (2): 212-244, https://doi.org/10.1080/15339 114.2013.816554.

Yoon, S. 2016. UN praises Korean rescue teams. Korea.net, 25 November. http://korea.net/ NewsFocus/policies/view?articleId=151092 (accessed 12 August 2018). 